\title{
Medium and large mammals of the mid Planas River basin, Colombia
}

\section{Mamíferos medianos y grandes de la cuenca media del río Planas, Colombia}

\author{
Carlos A. Aya-Cuero ${ }^{(i)}$, Federico Mosquera-Guerra ${ }^{(i)}$, Diego A. Esquivel ${ }^{\circ}$, Fernando Trujillo ${ }^{\circ}$ \\ and Daniel Brooks
}

\begin{abstract}
We describe the diversity of medium and large mammals from an area in the Colombian Orinoco River basin. For three years we systematically used camera traps at 72 sampling stations and walked forest and savanna transects to determine the diversity of medium and large mammals. Relative abundance was documented for 29 native and 2 feral mammals from a sampling effort of 1789 camera-days and $469.5 \mathrm{~km}$ walked. Thirty-one species of mammals (9 orders, 19 families) were recorded. Threatened species recorded included the giant armadillo (Priodontes maximus), lowland tapir (Tapirus terrestris), white-lipped peccary (Tayassu pecari), and giant anteater (Myrmecophaga tridactyla). The most abundant species were the collared peccary (Pecari tajacu) and the common opossum (Didelphis marsupialis). We recorded rare species, including the bush dog (Speothos venaticus) and the Llano semi-endemic long-nosed armadillo (Dasypus sabanicola). The species documented face diverse pressures, including development, hunting for subsistence, and competition with invasive species and livestock. Our results suggest that the surveyed areas are important for the conservation of mammals in the eastern plains of Colombia.
\end{abstract}

Keywords. Meta. Riparian forest. Savannas. Species composition.

\section{Resumen}

Estudiamos la diversidad de mamíferos medianos y grandes en un área no protegida de la Orinoquia Colombiana durante tres años, empleando cámaras trampa en 72 estaciones de muestreo y haciendo recorridos por bosques y sabanas. Con un esfuerzo de 1789 días-cámara y $469.5 \mathrm{~km}$ recorridos se documentaron 31 especies de mamíferos (9 órdenes, 19 familias). Se registraron especies amenazadas como ocarro (Priodontes maximus), danta (Tapirus terrestris), pecarí de labio blanco (Tayassu pecari) y hormiguero gigante (Myrmecophaga tridactyla). Se registraron especies raras, como el perro vinagre (Speothos venaticus) y semiendémicas como el cachicamo sabanero (Dasypus sabanicola). Las especies mejor representadas a través del índice de abundancia relativa fueron el pecarí de collar (Pecari tajacu) y la zarigüeya (Didelphis marsupialis). Las especies registradas se enfrentan a diversas presiones, como cacería para subsistencia, especies invasoras y ganadería. Por lo tanto, los resultados sugieren que las áreas no protegidas son importantes para la conservación de los mamíferos en los Llanos Orientales de Colombia.

Palabras clave. Bosques de galería. Composición de especies. Meta. Sabanas. 


\section{Introduction}

Colombia is considered the sixth most species-rich country for mammals worldwide, with 528 species (Ramírez-Chaves et al., 2016; Ramírez-Chaves et al., 2019). This diversity is explained in part by its geographic position, and the different climates, altitudes, and ecosystems represented in the country's six biogeographic regions (Andean, Amazon, Caribbean, Guyana, Pacific, and Orinoquia; Trujillo et al., 2018). The Orinoquia, also known as the Llanos Orientales (eastern plains), occupies ca. 17 million ha (Rippstein et al., 2001), 18\% of the country's land area, and contains multiple ecosystems, including savannas, wetlands, and a variety of forests (e.g., morichal or Mauritia swamps, transitional, and gallery forests; Buriticá, 2016). The mammalian fauna of the Orinoco River basin is shaped by Andean, Amazonian, and Guiana Shield elements (Correa et al., 2006), and it is estimated that the largest population concentrations of mammals are located in this biogeographic region (Rodríguez-Mahecha et al., 2006). In contrast, this region harbors a relatively low level of endemism (Rodríguez-Mahecha et al., 2006; Ferrer et al., 2009).

Despite the high biodiversity and studies recently conducted of the region's medium and large mammals (Álvarez \& López-Arévalo, 2014; Rodríguez-Bolaños et al., 2015; Olarte-González \& Balaguera-Reina, 2015; Mosquera-Guerra et al., 2017; Mosquera-Guerra et al., 2018; Trujillo et al., 2018; Castillo-Figueroa et al., 2019; Pardo et al., 2019), the mammals of the Orinoco River basin are among the least known in Colombia (Hernández et al., 1984; Mosquera-Guerra et al., 2018). The cited studies have a low representatioforest fragmentedn contrast to the size of the Orinoquia and its habitat heterogeneity. Therefore, it is necessary to keep on gathering information on distribution, conservation, and threats (Mosquera-Guerra et al., 2017), since there are still information gaps that hinder the designation of priority zones for mammal conservation.

Zones outside protected areas constitute an important aspect in the conservation of large mammals (Payán-Garrido \& Escudero-Páez, 2015). Although the total proportion of legally protected areas in Colombia is slightly larger than the global average of $14.7 \%$ (UN Environment WCMC, 2018), these reserves alone will not protect most of the biodiversity in the longterm (Rosenzweig, 2003; Brooks et al., 2004; Rodrigues et al., 2004). The protected areas are and will remain too small, isolated and vulnerable to natural and anthropogenic changes (Hales, 1989; Van Schaik et al., 1997; Carroll et al., 2004; DeFries et al., 2005). Forest cover changes in the Orinoco basin have intensified after human activity increased since ca. 1950 (Trujillo \& Superina, 2013), and the area has suffered a reduction in the quantity and quality of available habitat. Therefore, further data are necessary to track subsequent changes in species composition and density (Lasso et al., 2011).

Our objective in this study is to describe the diversity of medium and large mammals in the mid Planas River basin, an unprotected area located in Puerto Gaitán, Meta Department. This study was undertaken using 'bycatch' photo-trap data from armadillo conservation projects in the Colombian Llanos (Superina et al., 2019) and autoecological research of the giant armadillo Priodontes maximus in Puerto Gaitán (Aya-Cuero et al., 2017).

\section{Materials and methods}

Study site. The study area comprises ten private properties (ca. 30700 ha surveyed) located in the mid Planas River basin (ca. 369530 ha; Forero, 2017), near the municipality of Puerto Gaitán, Meta, Colombia $\left(4^{\circ} 1^{\prime} 56^{\prime \prime} \mathrm{N}\right.$, $\left.71^{\circ} 49^{\prime} 40^{\prime \prime} \mathrm{W}\right)$. The Planas River watershed is one of the most extensive forested areas of the municipality, with over 250 tree species, but has suffered a high degree of change in vegetation cover recently (Correa et al., 2006; Forero, 2017). The following types of forest cover have been documented in the region: riparian, terra firme, fragmented, freshwater swamp, morichal (Mauritia flexuosa palm swamps), and secondary tall forest, as well as wooded pasture, and savanna (Forero, 2017). Overall, the area is $90 \%$ plains and $10 \%$ mountains (Cicery et al., 2005), 
corresponding to high plains without seasonal flooding (Rangel-Ch et al., 1995). Average annual rainfall is 2300 $\mathrm{mm}$, with a bimodal rainfall regime, and temperature renges between 24 and $30^{\circ} \mathrm{C}$ (Cicery et al., 2005). The area is classified as a seasonal tropical savanna pedobiome, characterized by extensive savannas and wooded vegetation restricted to gallery forests (Hernández-Camacho et al., 1992).

Fieldwork. We used 20 Bushnell Trophy Cam, ScoutGuard, Cuddeback Attack, DLC Covert II and Reconyx PC camera traps with active motion detection. The cameras were installed at 72 sampling sites (Figure 1; Table 1) between 2013 and 2015, with the following seasonal effort per year (season/trap-days): 2013 (rainy - 95, dry - 55), 2014 (rainy-250, dry-1209) and 2015 (rainy -180), camera traps were installed $50 \mathrm{~cm}$ above the ground, located primarily at armadillo burrows, trails, and watering holes, with inter-camera distances ranging from $500-1000 \mathrm{~m}$. Each camera was georeferenced using a global positioning system (GPSMAP® 62sc | Garmin). Camera traps were programed to operate $24 \mathrm{hrs} /$ day with an interval of 3 minutes between each pictures record. Finally, the sampling effort was calculated according to Díaz-Pulido \& Payán (2012) and Lira-Torres \& Briones-Salas (2012).

In 2014 different transects were walked daily by one person (occasionally two) between 6:00 and 9:00 hrs.

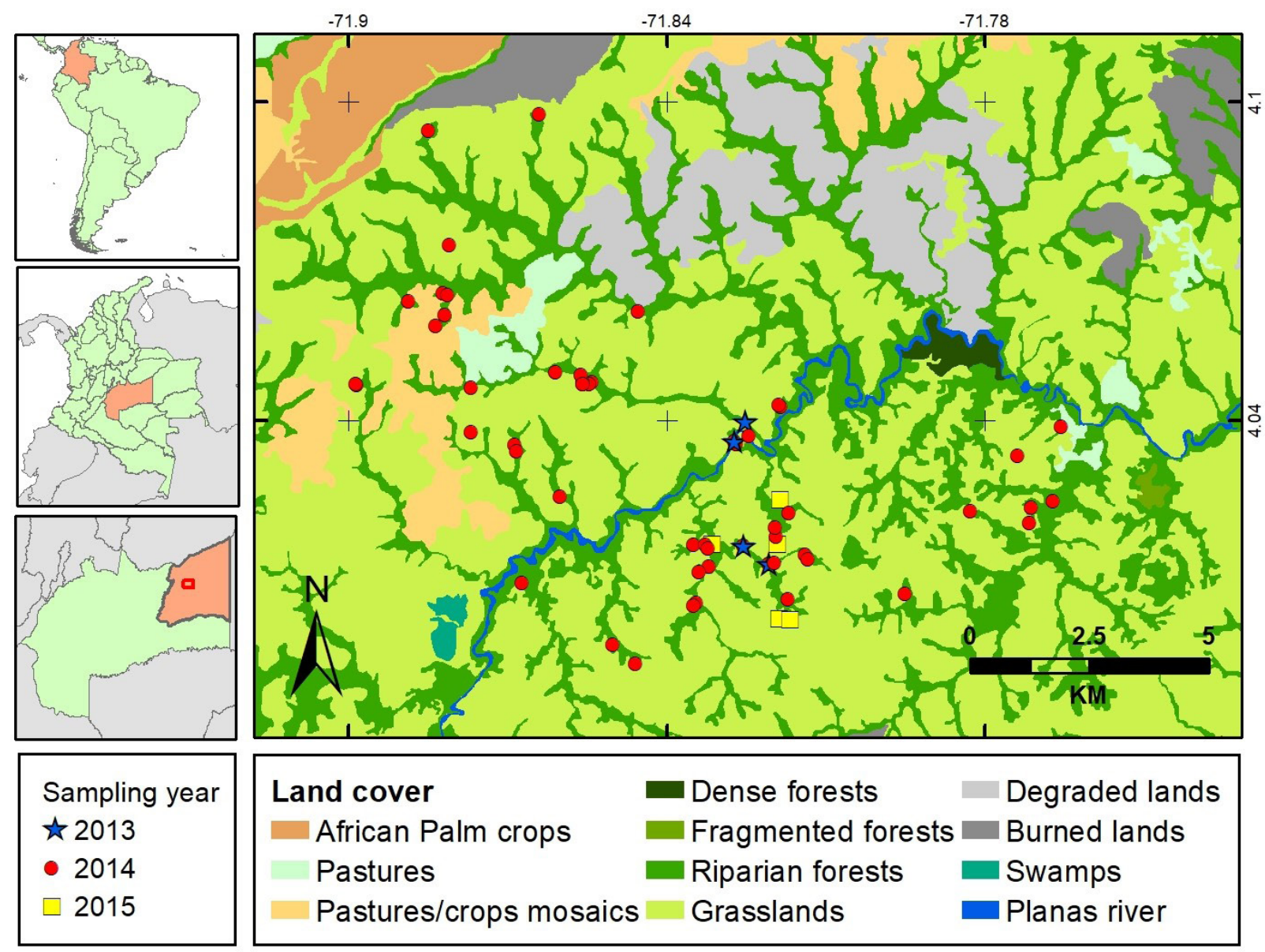

Figure 1. Planas River basin in Puerto Gaitán (Meta, Colombia), with land covers and mammal sampling stations. Stars, 2013 sampling; circles, 2014 sampling: squares, 2015 sampling. 
Transect length ranged between $1.5 \mathrm{~km}$ (195 repeats) along gallery forests and $0.5 \mathrm{~km}$ (254 repeats) along wooded savannas. We recorded direct sightings and indirect evidence of mammals, which were registered, georeferenced, and photographed.

Semi-structured interviews were conducted among 45 local people of Vereda Santa Catalina and Vereda Alto Manacacías between February 8th and August 14th, 2014, to obtain data on uses of fauna and the primary threats to certain species. We asked about uses of the species, considering the following topics for wild mammals: retaliation hunting, protein source, local threats, medicinal and other uses. Interviewees were shown illustrations of Linares (1998) and Emmons \& Feer (1997) for species identification.

Specimens found dead or displayed as hunting trophies were collected and deposited at the biological collections of the Museo de Historia Natural de la Universidad Distrital Francisco José de Caldas (MHNUD) and the Museo de La Salle (MLS-BOG). The only reference available for this area, Rodríguez-Bolaños et al. (2015), was included to confirm the presence of certain species in the Planas River basin.

Medium and large size mammals were identified using the taxonomic guides of Linares (1998), Gardner (2008), Patton et al. (2015), and taxonomy follows Wilson \& Reeder (2005), Ramírez-Chaves et al. (2019), and specialized papers for each group. To identify the threat category, the National Red List for mammals of Colombia was used (Minambiente, 2017), as well as the IUCN Red List (IUCN, 2019).

Statistical Analysis. Sampling effort was calculated by multiplying the number of camera traps by the number of effective sampling days $(1$ day $=24 \mathrm{hrs}$; Lira-Torres \& Briones-Salas, 2012). Additionally, the relative abundance index (RAI) was calculated for each species by dividing the number of records per taxon by the total number of camera trap records (Díaz-Pulido \& Payán-Garrido, 2012).

\section{Results}

A total of 588 records were obtained from a sampling effort of 1789 camera-days (Table 1). These records accounted for 31 species of medium and large mammals ( 29 natives, 2 feral species) from 19 families in 9 orders (Table 2, Figure 2). IUCN Red-listed species accounted for $23.3 \%$ of all identified species, including Priodontes maximus (VU), Tapirus terrestris (VU), Myrmecophaga tridactyla (VU), Tayassu pecari (VU), Dasypus sabanicola (NT), Speothos venaticus (NT), and Lontra longicaudis (NT).

The lowest RAI (RAI = 0.001) was for C. lanatus, which was found only once during the sampling effort; in contrast, P. tajacu $(\mathrm{n}=203$; RAI $=0.222)$ and $D$. marsupialis $(\mathrm{n}=168$; RAI $=0.184)$ had the highest RAI values (Figure 3).

Table 1. Sampling effort of camera trapping for medium and large mammals at the mid Planas River, Meta, Colombia.

\begin{tabular}{llccc}
\hline Year & Date & \# traps/stations & Sampling days & Effort (trap-days) \\
\hline 2013 & 5 - 23 August & $5 / 5$ & 19 & 95 \\
\hline & 1 - 11 March & $5 / 5$ & 11 & 55 \\
\hline 2014 & 10 February - 8 August & $10 / 50$ & 133 & 1335 \\
\hline & 2 - 30 November & $6 / 6$ & 20 & 124 \\
\hline 2015 & 23 July - 23 August & $6 / 6$ & 30 & 180 \\
\hline & TOTAL & $42 / 72$ & 213 & 1789 \\
\hline
\end{tabular}


Table 2. Medium-sized to large mammals recorded in mid Planas River basin, Meta, Colombia. Records to genus are not included in the species count. Conservation status follows IUCN Red List (2018) and Rodríguez et al. (2006): LC, Least Concern; NT, Near Threatened; VU, Vulnerable. Type of records: Ct, camera trap; Ho, human observation; In, interview; Ir, indirect record; Li, literature; Pa, parts of dead animals. RAI, relative abundance index. Forest Cover: Gf, gallery forest; M, Morichal; Sa, high-plain savannas. *Species recorded by Rodríguez-Bolaños et al. (2015).

\begin{tabular}{|c|c|c|c|c|c|c|c|c|}
\hline \multirow[t]{3}{*}{ Species } & \multirow[t]{3}{*}{ Voucher } & \multicolumn{2}{|c|}{ Conservation status } & \multicolumn{3}{|c|}{ Records } & \multicolumn{2}{|r|}{$\begin{array}{l}\text { Forest } \\
\text { cover }\end{array}$} \\
\hline & & & MIN- & & & & & \\
\hline & & IUCN & $\begin{array}{c}\text { AMBIENTE } \\
(2017)\end{array}$ & 2103 & 2014 & 2015 & RAI & \\
\hline \multicolumn{9}{|l|}{ DIDELPHIMORPHIA } \\
\hline \multicolumn{9}{|l|}{ Didelphidae } \\
\hline Didelphis marsupialis* & $\begin{array}{l}\text { [MHNUD-795]: } \\
\text { skull and skin }\end{array}$ & LC & - & $\mathrm{Ct}(6)$ & $\begin{array}{c}\text { Ct (149), } \\
\mathrm{Pa}(1), \\
\mathrm{In}(28)\end{array}$ & $\begin{array}{c}\mathrm{Ct}(13), \mathrm{Li} \\
(1)\end{array}$ & 0.187 & Gf \\
\hline Caluromys lanatus & & LC & - & $\mathrm{Ct}(1)$ & & & 0.001 & Gf \\
\hline Metachirus nudicaudatus* & & LC & - & $\mathrm{Ct}(1)$ & $\mathrm{Ct}(3)$ & $\operatorname{Li}(1)$ & 0.004 & Gf \\
\hline \multicolumn{9}{|l|}{ CINGULATA } \\
\hline \multicolumn{9}{|l|}{ Dasypodidae } \\
\hline Dasypus novemcinctus* & LC & - & $\mathrm{Ct}(1)$ & & $\begin{array}{l}\text { Ct (7), } \\
\text { Pa (6), } \\
\text { In (19) } \\
\end{array}$ & $\begin{array}{c}\mathrm{Ct}(3), \mathrm{Li} \\
(1)\end{array}$ & 0.014 & Gf, M \\
\hline Dasypus pastasae & $\begin{array}{l}\text { [MHNUD- 807]: } \\
\text { carapace; [MLS- } \\
\text { 2430]: skull }\end{array}$ & LC & - & $\mathrm{Ct}(5)$ & $\begin{array}{c}\mathrm{Ct}(84), \\
\mathrm{Pa}(2), \mathrm{Ir} \\
(3), \\
\operatorname{In}(26) \\
\end{array}$ & $\mathrm{Ct}(2)$ & 0.101 & Gf, Sa \\
\hline Dasypus sabanicola* & $\begin{array}{c}\text { [MHNUD-796]: } \\
\text { skin; } \\
\text { [MHNUD-806]: } \\
\text { skin } \\
\end{array}$ & NT & - & $\begin{array}{l}\text { Ho (1), } \\
\text { Ct (2) }\end{array}$ & $\begin{array}{l}\mathrm{Ct}(6), \\
\mathrm{Ho}(2), \\
\mathrm{Pa}(2), \\
\mathrm{In}(35)\end{array}$ & $\mathrm{Li}(1)$ & 0.009 & Sa, Gf, M \\
\hline Dasypus spp. & & - & - & $\mathrm{Ct}(8)$ & $\mathrm{Ct}(45)$ & & 0.059 & Gf, Sa, M \\
\hline \multicolumn{9}{|l|}{ Chlamyphoridae } \\
\hline Priodontes maximus* & $\begin{array}{c}\text { [MHNUD-810]: } \\
\text { carapace; [MLS- } \\
\text { 1844]: skull; } \\
\text { [MHNUD-808]: } \\
\text { carapace } \\
\end{array}$ & $\mathrm{VU}$ & $\mathrm{EN}$ & $\begin{array}{l}\mathrm{Pa}(1), \\
\mathrm{Ct}(3),\end{array}$ & $\begin{array}{l}\text { Ct (85), } \\
\mathrm{Ho}(3), \\
\mathrm{Pa}(2), \\
\mathrm{In}(17)\end{array}$ & $\begin{array}{c}\mathrm{Ct}(1), \mathrm{Li} \\
(1)\end{array}$ & 0.099 & Gf, Sa \\
\hline \multicolumn{9}{|l|}{ PILOSA } \\
\hline Myrmecophagidae & & & & & & & & \\
\hline
\end{tabular}




\begin{tabular}{|c|c|c|c|c|c|c|c|c|}
\hline Tamandua tetradactyla* & Not Collected & $\mathrm{LC}$ & - & $\mathrm{Ct}(2)$ & $\begin{array}{l}\text { Ho (2), } \\
\mathrm{Ct}(11), \\
\mathrm{Pa}(2), \\
(\mathrm{In} 32)\end{array}$ & $\begin{array}{c}\mathrm{Ct}(2), \mathrm{Li} \\
(1)\end{array}$ & 0.017 & Gf \\
\hline Myrmecophaga tridactyla & & VU & VU & $\mathrm{Ct}(2)$ & $\begin{array}{l}\text { Ct (12), } \\
\text { Ho (2), } \\
\text { In (41) }\end{array}$ & & 0.016 & Gf, Sa \\
\hline
\end{tabular}

\begin{tabular}{|c|c|c|c|c|c|c|c|c|}
\hline \multicolumn{9}{|l|}{ Felidae } \\
\hline Leopardus pardalis* & & LC & - & $\mathrm{Ct}(4)$ & $\begin{array}{c}\mathrm{Ct}(5), \\
\mathrm{Pa}(16)\end{array}$ & $\mathrm{Li}(1)$ & 0.010 & Gf \\
\hline Puma concolor & Not Collected & $\mathrm{LC}$ & - & $\mathrm{Ct}(3)$ & $\begin{array}{l}\mathrm{Ct}(3) \\
\mathrm{In}(14)\end{array}$ & $\mathrm{Pa}(1)$ & 0.007 & Gf \\
\hline \multicolumn{9}{|l|}{ Canidae } \\
\hline Speothos venaticus & & NT & - & $\mathrm{Ct}(2)$ & $\mathrm{Ct}(1)$ & & 0.003 & Gf \\
\hline Cerdocyon thous & $\begin{array}{l}\text { [MHNUD-802]: } \\
\text { skull; } \\
\text { [MHNUD-803]: } \\
\text { skull }\end{array}$ & LC & - & $\mathrm{Ct}(1)$ & $\begin{array}{l}\mathrm{Ct}(8), \\
\mathrm{Ho}(3), \\
\mathrm{Pa}(2), \\
\text { In (43) }\end{array}$ & & 0.010 & Gf, Sa \\
\hline Canis familiaris & & - & - & & $\mathrm{Ct}(3)$ & & 0.003 & Gf \\
\hline \multicolumn{9}{|l|}{ Mustelidae } \\
\hline Eira barbara* & & LC & - & & $\begin{array}{l}\mathrm{Ct}(7) \\
\text { Ho (3) }\end{array}$ & $\begin{array}{c}\mathrm{Ct}(2), \mathrm{Li} \\
\text { (1) }\end{array}$ & 0.010 & Gf \\
\hline Lontra longicaudis & & $\mathrm{NT}$ & VU & & $\begin{array}{l}\text { Ho (1), } \\
\text { In (17) }\end{array}$ & & - & Gf \\
\hline
\end{tabular}

Tapiridae

\begin{tabular}{|c|c|c|c|c|c|c|c|c|}
\hline Tapirus terrestris & $\begin{array}{c}\text { [MHNUD- sn]: } \\
\text { skull }\end{array}$ & VU & - & $\mathrm{Ct}(2)$ & $\begin{array}{c}\text { Ho (1), } \\
\text { Ir (7), } \\
\text { In (13) }\end{array}$ & $\mathrm{Pa}(1)$ & 0.002 & Gf, M \\
\hline
\end{tabular}

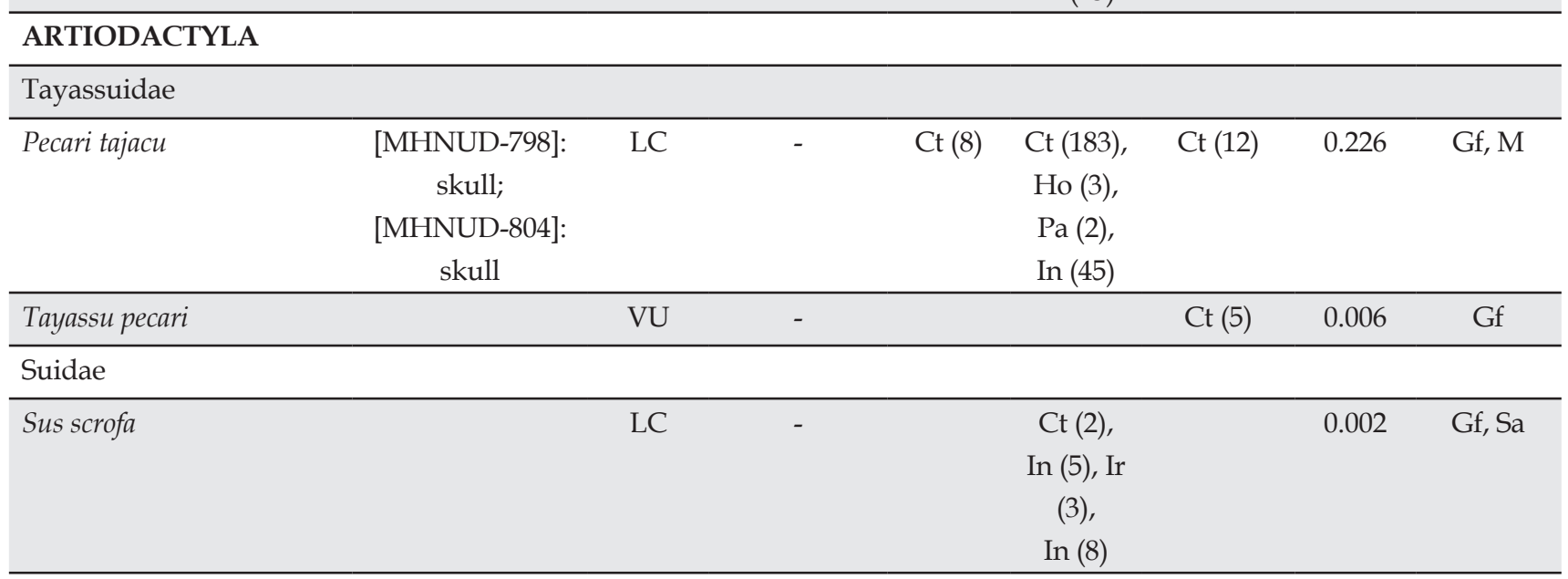




\begin{tabular}{|c|c|c|c|c|c|c|c|c|}
\hline Cervidae & & & & & & & & \\
\hline Odocoileus cariacou & $\begin{array}{c}\text { [MHNUD-800]: } \\
\text { skull }\end{array}$ & - & $\mathrm{CR}$ & $\mathrm{Pa}(1)$ & $\begin{array}{l}\text { Ct (4), } \\
\text { Ho (3), } \\
\text { In (25) }\end{array}$ & & 0.004 & Gf, Sa \\
\hline LAGOMORPHA & & & & & & & & \\
\hline Leporidae & & & & & & & & \\
\hline Sylvilagus brasiliensis & & $\mathrm{LC}$ & - & Ho (1) & $\begin{array}{l}\text { Ho (5), } \\
\text { In (32) }\end{array}$ & & - & $\mathrm{Sa}$ \\
\hline PRIMATES & & & & & & & & \\
\hline Atelidae & & & & & & & & \\
\hline Alouatta seniculus & & $\mathrm{LC}$ & - & & $\begin{array}{c}\text { Ho (4), } \\
\operatorname{Ir}(8)\end{array}$ & & - & Gf \\
\hline Cebidae & & & & & & & & \\
\hline Cebus albifrons & $\begin{array}{c}\text { [MHNUD- sn]: } \\
\text { skull }\end{array}$ & $\mathrm{LC}$ & - & & $\mathrm{Pa}(1)$ & Ho (2) & - & Gf \\
\hline Sapajus apella* & & $\mathrm{LC}$ & - & & $\operatorname{In}(6)$ & $\mathrm{Li}(1)$ & - & Gf \\
\hline Saimiri cassiquiarensis & & $\mathrm{LC}$ & - & & $\begin{array}{l}\text { Сa (1), } \\
\text { Нo (3) }\end{array}$ & & & Gf \\
\hline RODENTIA & & & & & & & & \\
\hline Sciuridae & & & & & & & & \\
\hline Notosciurus cf. granatensis & & $\mathrm{LC}$ & - & & $\begin{array}{l}\text { Ct (25), } \\
\text { Ho (8), } \\
\text { In (23) }\end{array}$ & Ho (2) & 0.031 & Gf \\
\hline Caviidae & & & & & & & & \\
\hline Hydrochoerus hydrochaeris & Not collected & $\mathrm{LC}$ & - & & $\begin{array}{c}\text { Ho (2), } \\
\text { Pa (1), } \\
\text { In (6) }\end{array}$ & & - & Gf, M \\
\hline Cuniculidae & & & & & & & & \\
\hline Cuniculus paca* & $\begin{array}{c}\text { [MHNUD-799]: } \\
\text { skull; } \\
\text { [MHNUD-805]: } \\
\text { skull }\end{array}$ & $\mathrm{LC}$ & - & $\mathrm{Ct}(9)$ & $\begin{array}{l}\text { Ct (72), } \\
\text { Ho (2), } \\
\text { In (45) }\end{array}$ & $\mathrm{Ct}(17)$ & 0.109 & Gf \\
\hline Dasyproctidae & & & & & & & & \\
\hline Dasyprocta fuliginosa* & $\begin{array}{c}\text { [MHNUD-797]: } \\
\text { skin and skull; } \\
\text { [MHNUD-809]: } \\
\text { skull; } \\
\text { [MHNUD-801]: } \\
\text { skull }\end{array}$ & $\mathrm{LC}$ & - & $\mathrm{Ct}(12)$ & $\begin{array}{l}\mathrm{Ct}(45), \\
\mathrm{Pa}(3) \\
\mathrm{In}(38)\end{array}$ & $\mathrm{Ct}(3)$ & 0.067 & Gf \\
\hline Erethizontidae & & & & & & & & \\
\hline Coendou prehensilis* & & LC & - & & In (6) & $\mathrm{Li}(1)$ & - & Gf \\
\hline
\end{tabular}



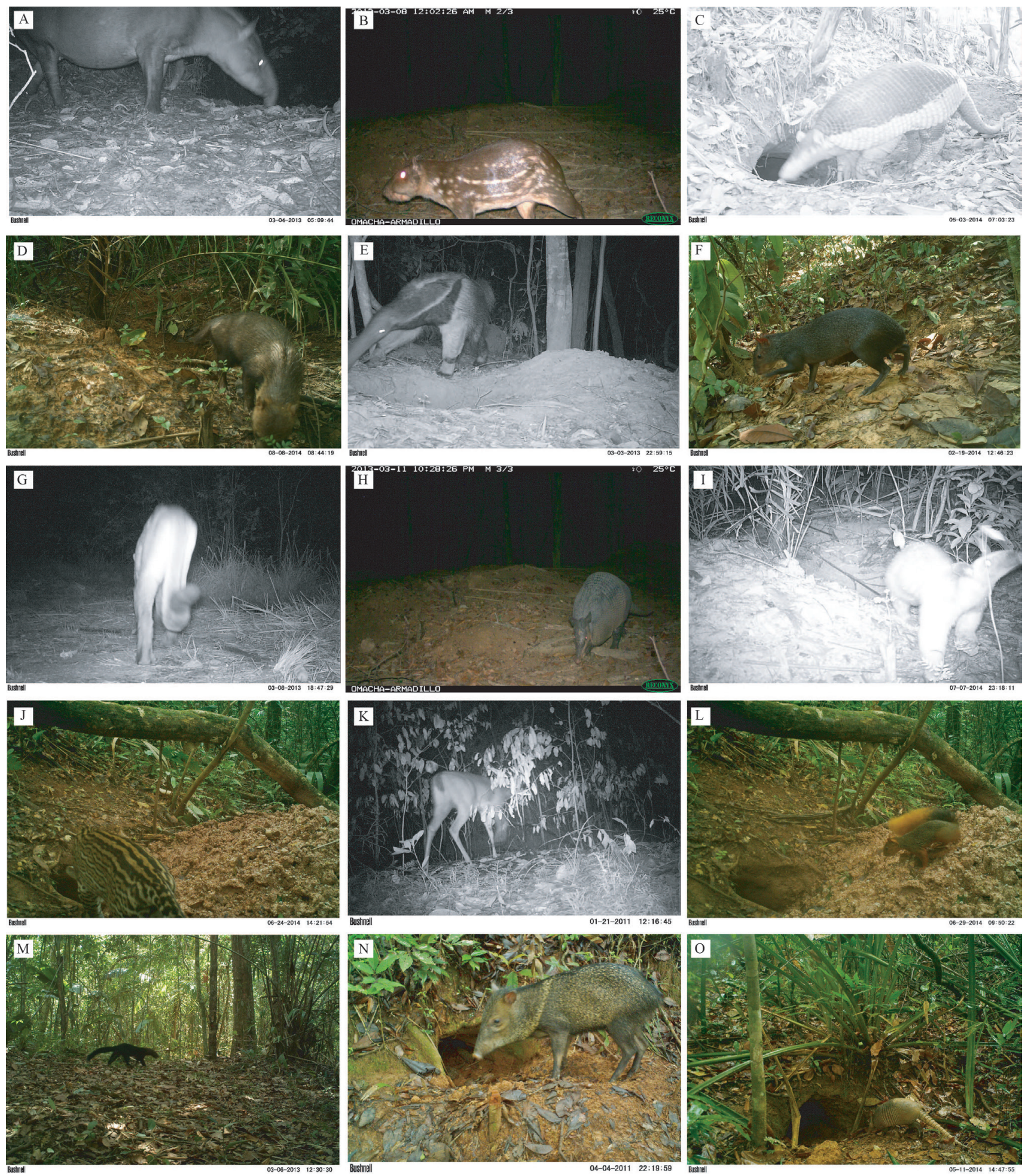

Figure 2. Mammals recorded with camera traps at the mid Planas River basin, Puerto Gaitán, Meta, Colombia. A) Tapirus terrestris, B) Cuniculus paca, C) Priodontes maximus, D) Speothos venaticus, E) Myrmecophaga tridactyla, F) Dasyprocta fuliginosa, G) Puma concolor, H) Dasypus pastasae, I) Tamandua tetradactyla, J) Leopardus pardalis, E) Odocoileus cariacou, L) Notosciurus cf. granatensis, M) Eira barbara, N) Pecari tajacu, and O) Dasypus sabanicola. 


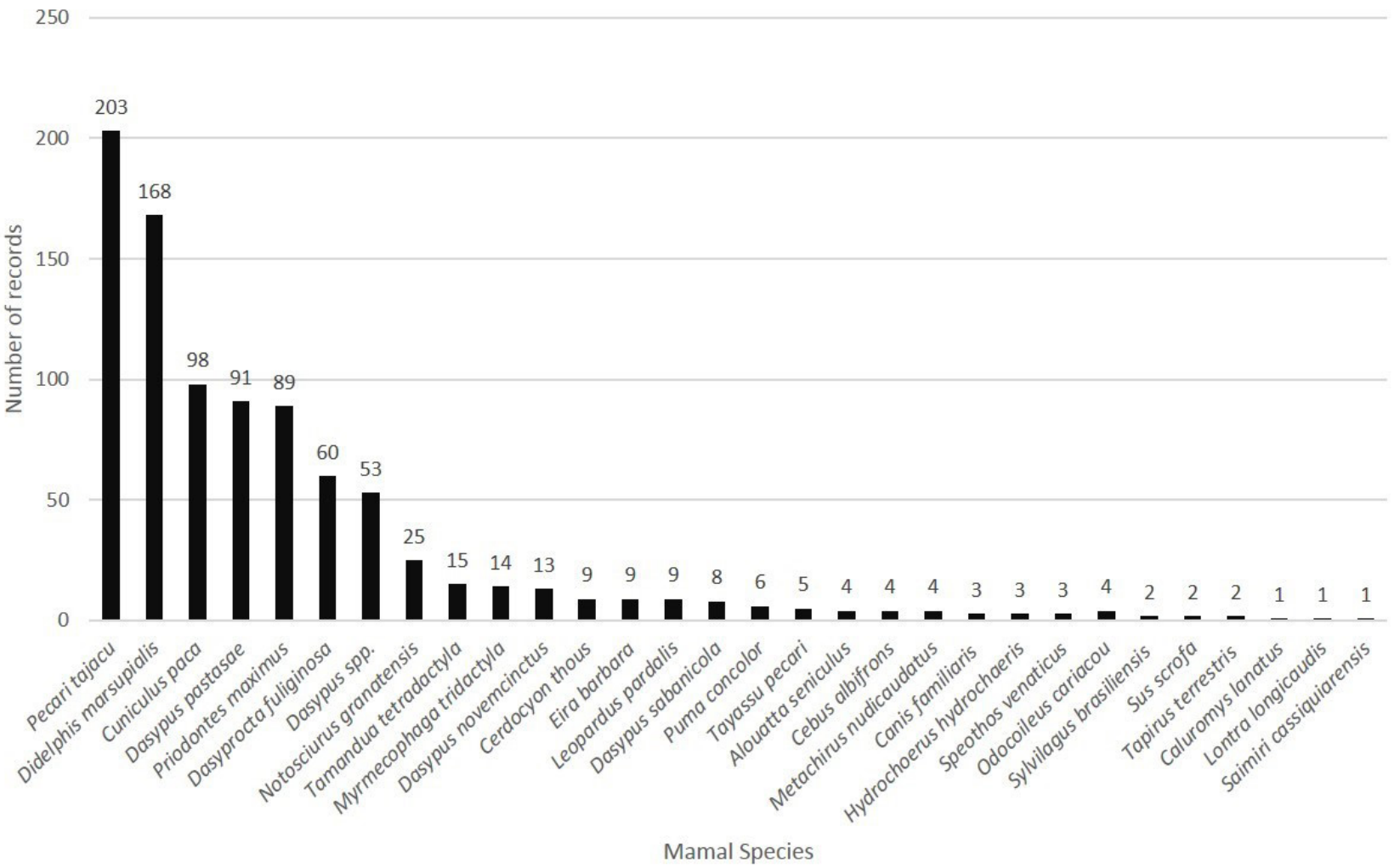

Figure 3. Number of records obtained with camera traps for medium and large mammals in the mid Planas River basin, Meta, Colombia.

The local community uses mammals in various ways: $52 \%$ consume wild mammals as a source of protein for subsistence, $40 \%$ have medicinal uses for different animal parts, $5 \%$ hunt for recreation, and 3\% keep some mammals as pets. Most interviewees (82\%) identified armadillos (Dasypus spp.) and paca (C. paca) as the most important species for food consumption. In addition, local people recognize ungulates such as the lowland tapir, deer and peccaries as the most hunted mammals a decade ago. Nonetheless, people perceive that the number of mammals has decreased in recent years, the causes being identified by the community as hunting (30\%), dog kills (29\%), environmental pollution (19\%), wildlife-vehicle collisions (15\%), and fire (7\%).

During our fieldwork between February and August 2014, we recorded multiple evidence of mammals being used as a source of protein, hunting trophies, and pets.
We recorded the following species: D. pastasae (1), D. sabanicola (5), P. maximus (2), T. terrestris (1), D. fuliginosa (2), H. hydrochaeris (1), C. paca (3) C. albifrons (1) and O. cariacou (2). Other mammals were hunted because they posed a threat to livestock and poultry, including P. concolor (1) and D. marsupialis (1).

Specimens from the study area used as hunting trophies included ocelot (Leopardus pardalis) pelts, giant armadillo (P. maximus) carapaces, tails and carapaces of armadillos (Dasypus spp.), paca (C. paca) skulls, Coues' white-tailed deer $(O$. cariacou) antlers, and jaguar $(P$. onca) bones. The Jaguar bones came from the department of Vichada (bordering to the east) and they are used to treat burns and wounds.

Another threat documented in the study area was wildlife-vehicle collisions; $15 \%$ of the local communities 
have observed mammals involved in roadkills on tertiary roads in this area. During the field work three mammals were found dead along the Puerto Gaitán-Rubiales tertiary road: C. thous (1), D. pastasae (1) and T. tetradactyla (2). Also, stray or feral species such as dogs (C. familiaris; $\mathrm{n}=3$ events) and pigs ( $S$. scrofa; $\mathrm{n}=2$ ) present a threat from the hunting of wild species and competition for resources. Moreover, local people hunted with dogs, as evidenced for the following species: C. paca, D. marsupialis, Dasypus spp., T. terrestris, and $P$. concolor. Additional threats recognized by the local communities and the literature include African oil palm (Elaeis guineensis) crops, extensive livestock farming, changes in native forest cover, and habitat destruction through deliberate burning of savannas.

\section{Discussion}

Our study detected $57 \%$ more species of the native medium-sized to large terrestrial mammals compared to a study carried out in the same area by Rodríguez-Bolaños et al. (2015). Comparing with other non-protected areas of the Orinoco basin, we obtained 55\% more than that reported in others three types of savannas (Castillo-Figueroa et al., 2019), 45\% more than the African oil palm plantation, 21\% more than forest (Pardo et al. 2019), and 13\% more than the morichales (Trujillo et al., 2017). This indicates that the gallery forest is important as a biological corridor among the savannas and pastures; the probability of occurrence in these forests is considerably greater than in other types of forest cover. In addition, long-term studies are more effective for understanding species diversity in a non-protected area. However, in La Macarena National Natural Park, relatively close to our study area in the same department, Díaz-Pulido et al. (2016) recorded all the species found in our study, and $27 \%$ more, with a minor sampling effort. Nevertheless, according to Trujillo et al. (2018) the characteristics and landscape in that location are different, more closely associated with the Guianan region.
In general, the protected areas in the Orinoquia region are few (Romero et al., 2017). La Macarena, El Tuparro, and the flooded savannas of Cinaruco, in Arauca, are the only national protected areas in the Orinoquia and constitute a small portion of this important biogeographical region. It is questionable whether these protected areas in the Orinoquia region provide effective protection to medium and large mammals. At present, no protected biological corridors have been established between these protected areas. Therefore, there is no guarantee of quality or quantity of long-term habitat for wildlife conservation.

The association of giant armadillo burrows by wildlife in savanna ecosystems is an important topic. Aya-Cuero et al. (2017) documented different groups of vertebrates associated with $P$. maximus burrows at this same study area, among them 13 species of mammals, including P. tajacu and C. paca. These two species had high RAI values compared to other studies in the same region (e.g., Castillo-Figueroa et al., 2019; Pardo et al., 2019), probably due to their foraging and subterranean habits. The savanna ecosystem has few shelters compared to others ecosystems. Nonetheless, these ecosystems are home to keystone species and habitat engineers, such as large carnivores (P. concolor and L. pardalis; Garrote et al., 2017; Mosquera-Guerra et al., 2017), perissodactyls (T. terrestris), artiodactyls (T. pecari and O. cariacou), and xenarthrans (P. maximus and M. tridactyla; Muñoz-Saba et al., 2016; Aya-Cuero et al., 2017; Mosquera-Guerra et al., 2017).

The adequate identification of species from camera trap records is vital to avoid underestimating or overestimating the abundance of some species. Different studies have used camera traps to obtain data on medium and large mammals, during which $D$. pastasae was documented (Tobler et al., 2008; 2015; Aya-Cuero et al., 2017). It should be noted that nine-banded armadillo (D. novemcinctus) and greater long-nosed armadillo (D. pastasae) tend to be pooled as Dasypus spp., due to difficulties in differentiating the two species based on camera trap images (Aya-Cuero et al., 2019). Similarly, D. pastasae also inhabits areas where other members of the genus Dasypus can be found, such as the llano 
long-nosed armadillo D. sabanicola, of the Eastern Plains, which likely indicates that armadillo abundance in other biological surveys of the Orinoco basin has been under-reported or misrepresented.

Local uses for different species reduce mammal populations. Of the 30 species recorded, only 10 (33\%) are used by local communities. Among such uses, bushmeat is most common and comprises an activity focused on finding food. Although hunting is not practiced intensively, the populations of some species may be affected in the midterm, for species such as $P$. maximus and T. terrestris with intrinsically low rates of reproduction (Brooks \& Eisenberg, 1999). Most rural communities in this area live in poverty and economic margination, and their priorities are therefore focused on subsistence and use of natural resources, although often unsustainably (Bolkovic, 1999, Lorenzo-Monterrubio et al., 2007).

The medium and large orders of mammals are preferred sources of protein by local communities. Our study found that the mammals used as a protein source were Artiodactyla, Cingulata and Rodentia. Similarly, the orders Artiodactyla and Rodentia are the most used (for their high biomass) by two indigenous communities in El Tuparro Biosphere Reserve (Martínez et al., 2016). Similarly, the species we found most desired by hunters are similar to those reported for other Sikuani indigenous communities in the department of Vichada (Plata, 2006). Concordant with Martínez et al. (2016), we found primate consumption infrequent, and only a single hunting incident involving one specimen (C. albifrons) by Sikuni indigenous communities was found. Systematic research of subsistence hunting is necessary in our study area, to understand the effect of this activity on the potential decrease of mammal populations.

A rare species recorded in our study is $S$. venaticus, photographed on 8 August 2014 at 08:44:19 h. Additional records of this species at the same locality are documented in detail by Rodríguez-Castellanos et al. (2017). In contrast, a rare species we did not record in this region is the short-eared dog (Atelocynus microtis) which was found in the same department, near Restrepo, on the Río Ariari (Ayure \& González-Maya, 2014) and recently in La Macarena (Díaz-Pulido et al., 2016). For species recorded, our results are concordant with Castillo-Figueroa (2019), with the exception of Herpailurus yaguaroundi, which we did not record.

Three Near threatened species, D. sabanicola, S. venaticus, and L. longicaudis, have not yet been evaluated at the national level for Colombia (Rodríguez-Mahecha et al., 2006; Minambente, 2017). However, the semi-endemic D. sabanicola yielded one of the lowest RAI (0.009). Considering that it is one of the few Orinoquia endemics and in light of its relatively small area of distribution, it seems to be seriously affected by the constant changes to its habitat, which has resulted in a population decrease. For this reason, it has recently been reevaluated by IUCN and classified as Near Threatened (NT; Superina et al., 2014). We consider that future studies in this region can estimate population density of cryptic, semi-endemic and rare species such as $P$. maximus, $D$. sabanicola and S. venaticus.

Various threats reduce mammal populations in the Orinoquia region, and our study identified hunting as one of the principal threats for mammals, concordant with a study in El Tuparro Biosfere Reserve (Martínez et al., 2016). This activity is a potential factor that contributes to the reduction of mammal populations globally. For the endangered giant armadillo (P. maximus), Rodríguez-Mahecha et al. (2006) mentioned that it is easy prey for hunters because it cannot hide quickly, especially in open habitats. We found a high preference of $P$. maximus in riparian forest rather than savannas (Aya-Cuero et al., 2017), which may be a mechanism for this species to avoid being hunted. Perhaps the same is true with other species (e.g., D. sabanicola, P. tajacu, O. cariacou, and T. terrestris). Behavioral studies analyzing these patterns are needed to identify the responses of the different species in their adaptation process and ecological importance.

An emerging threat in the study area is the presence of feral animals, primarily dogs and pigs. Other studies have demonstrated the negative impact these species 
have as they disproportionately predate and unbalance native faunal population densities (Cruz-Reyes, 2009). Plant populations are also affected; for example, in the Mauritia palm swamps, pigs predate the palm fruits and prevent seedlings from developing (Trujillo \& Mosquera-Guerra, 2016). These two domestic mammals are also competing with wildlife for resources such as food and habitat.

This study emphasizes the importance of private lands and non-protected areas as natural corridors for mammals, and as tools for faunal conservation in Meta department, as pointed out in studies conducted in the departments of Amazonas (Payán-Garrido \& Escudero-Páez, 2015) and Vichada (Mosquera-Guerra et al., 2017). Colombia has one of the highest proportions of protected areas with land and forest degradation (Leisher et al., 2013), with $4.9 \%$ of its protected areas subjected to intense human pressures (Jones et al., 2018). This is especially true in the Orinoco basin since it is one of the regions of Colombia with the least amount of protected areas (Romero et al., 2017). We recommend the promotion of private natural reserves, focusing on goals and activities related to conservation of key species such as $P$. maximus, $S$. venaticus and $T$. terrestris.

\section{Acknowledgements}

This study was funded by the Conservation Program on Armadillos of the Eastern Floodplains of Colombia, established by Fundación Oleoducto Vivo, Cormacarena, Corporinoquia, Corpometa, Bioparque Los Ocarros, and Fundación Omacha under cooperation agreement PE. DGE. 1.4.8.1.13.002. The authors would like to thank Fabián Cote for creating the map of the study area, and Abelardo Rodríguez for lending field equipment. We are indebted to Sabrina Dahlgren for translating this manuscript, and to Lyndon Carvajal for providing key literature. We thank the local communities and farm owners of the Planas River basin for letting us work on their land, especially Alirio Balaguera, president of the Junta de Acción Comunal for Santa Catalina municipality. We thank the curators from the Museo de
La Salle (MLS-BOG) and the Museo de Historia Natural de la Universidad Distrital (MHNUD) for their collaboration.

\section{References}

Álvarez, Z. \& López-Arévalo, H. (2014). Caracterización de medianos y grandes mamíferos en paisajes dominados por palma (Elaeis guineensis) en el departamento del Meta, Colombia. Program and memories of IV Congreso Colombiano de Zoología "La biodiversidad sensible: patrimonio natural irremplazable". Cartagena, Colombia. 357 pp.

Aya-Cuero, C., Chacón-Pacheco, J. \& Anacleto, T. (2019). Dasypus kappleri (Cingulata: Dasypodidae). Mammalian Species, 51 (977): 51-60.

Aya-Cuero, C., Rodríguez-Bolaños, A. \& Superina, M. (2017). Population density, activity patterns, and ecological importance of giant armadillos (Priodontes maximus) in Colombia. Journal of Mammalogy, 98, 770-778. https:// doi.org/10.1093/jmammal/gyx006 Ayure, S. \& González-Maya, J. (2014). Registro notable del Perro de Orejas Cortas Atelocynus microtis (Carnivora: Canidae) en el trapecio amazónico, Colombia. Mammalogy Notes, 1(1), 6-7.

Bolkovic, M. L. (1999). Usos de fauna silvestre de pobladores de las cercanías de la Reserva Provincial Copo, Santiago del Estero, Argentina. En: Fang, T. G., Montenegro, O.L. \& Bodmer, R. E. (Eds.). Manejo de la Fauna Silvestre en América latina. Pp: 117-124. La paz, Bolivia: Instituto de ecología.

Brooks, D. M. \&. Eisenberg, J. F. (1999). Estado y biología de los tapires neotropicales: perspectiva general. En Fang, T. G., Montenegro, O. L. \& Bodmer, R. E. (Eds.). Manejo de la Fauna Silvestre en América latina. Pp: 409413. La paz, Bolivia: Instituto de ecología.

Brooks, T. M., Bakarr, M. I., Boucher. T., Da Fonseca, G. A. B., Hilton-Taylor, C., Hoekstra, J. M., Moritz, T., Oliver, S., Parrish, J., Pressey, R. L., Rodrigues, A. S. L., Sehrest, W., Statersfield, A. \& Strahm, W. (2004). Coverage provided by the global protectedarea system: Is it enough? Bioscience, 54, 1081-1091. https:// doi.org/10.1641/0006-3568(2004)054[1081: CPBTGP]2.0.CO;2 
Buriticá, N. (2016). Descripción de estrategias complementarias de conservación y estrategias de conservaciónproducción relacionadas con Sabanas Inundables de la Orinoquia colombiana. Bogotá D.C.: Instituto de Investigación de Recursos Biológicos Alexander von Humboldt. 190 pp.

Carroll, C., Noss, R. F., Paquet, P. C. \& Shumaker, N. H. (2004). Extinction debt of protected areas in developing landscapes. Conservation Biology, 18, 1110-1120. https://doi.org/10.1111/j.1523-1739.2004.00083.x

Castillo-Figueroa, D., Martínez-Medina, D. Rodríguez-Posada, M. E. \& Bernal-Vergara, S. (2019). Structural differences in mammal assemblages between savanna ecosystems of the Colombian Llanos. Papéis Avulsos de Zoologia, 59, 1-11. https:/ / doi. org/10.11606/1807-0205/2019.59.14

Cicery, E., Gualtero, L. \& Cicery, R. (2005). Monografía del municipio de Puerto Gaitán, visión geohistórica y cultural. Puerto Gaitán.105 pp.

Correa, H. D., Arévalo, L. \& Ruiz, S. (2006). Plan de acción en biodiversidad de la cuenca del OrinocoColombia 2005-2015. (Propuesta técnica). Bogotá D.C.: Corporinoquia, Cormacarena, IAvH, Unitrópico, Fundación Omacha, Fundación Horizonte Verde, Universidad Javeriana, Unillanos, WWF - Colombia, GTZ - Colombia. 273 pp.

Cruz-Reyes, A. (2009). Fauna feral, fauna nociva y zoonosis. Biodiversidad del ecosistema del Pedregal de San Angel. Restauración, conservación y manejo, 453461.

DeFries, R., Hansen, A., Newton A. C. \& Hansen, M. C. (2005). Increasing isolation of protected areas in tropical forests over the past twenty years. Ecological Applications, 15, 19-26. https://doi.org/10.1890/03-5258

Díaz-Pulido, A. \& Payán-Garrido, E. (2012). Manual de fototrampeo: una herramienta de investigación para la conservación de la biodiversidad en Colombia. Bogotá D.C.: Instituto de Investigaciones de Recursos Biológicos Alexander von Humboldt y Panthera Colombia. 32 pp.

Díaz-Pulido, A., Velásquez, T., López, A., Alfonso, A. \& Mantilla-Meluk, H. (2016). Mamíferos. In Lasso, C. A. \& Morales-Betancourt M. A. (Eds.). III. Fauna de Caño Cristales, sierra La Macarena, Meta, Colombia.
Serie Editorial Fauna Silvestre Neotropical. Pp. 157183 Bogotá: Instituto de Investigación de Recursos Biológicos Alexander von Humboldt (IAvH).

Emmons, L. \& Feer, F. (1997). Neotropical rainforest mammals: a field guide. Chicago: University of Chicago press. 380 pp.

Ferrer, A., Beltrán, M., Díaz-Pulido, A., Trujillo, F., Mantilla-Meluk, H., Herrera, O., Alfonso, A. \& PayánGarrido, E. (2009). Lista de los mamíferos de la cuenca del río Orinoco. Biota Colombiana, 10, 179-207.

Forero, J. A. (2017). Plantas útiles de las cuencas de los ríos Tillavá y Planas en el municipio de Puerto Gaitán, Meta. (Trabajo de grado). Bogotá D.C.: Universidad Distrital Francisco José de Caldas, Facultad de Ciencias y Educación. 110 pp.

Gardner, A. L. (2008). Mammals of South America, volume 1: marsupials, xenarthrans, shrews, and bats. Chicago, EE.UU.: University of Chicago Press. 690 pp. https://doi.org/10.7208/chicago/9780226282428.001.0001

Garrote, G., Rodríguez-Castellanos, F., Trujillo, F. \& Mosquera-Guerra, F. (2017). Características de los ataques de jaguar (Panthera onca) sobre el ganado y evaluación económica de las pérdidas en fincas ganaderas de los Llanos Orientales (Vichada, Colombia). In Castaño-Uribe, C., Lasso, C., Hoogesteijn, R. \& Payán-Garrido, E. (Eds.). II. Conflicto entre felinos y humanos en América Latina. Pp: 89-102. Bogotá, D. C.: Serie Editorial Fauna Silvestre Neotropical, Instituto de Investigación de Recursos Biológicos Alexander von Humboldt.

Hales, D. (1989). Changing concepts of national parks. In Western, D. \& Pearl, M. C. (Eds.). Conservation for the twenty-first century. Pp: 139-144. New York: Oxford University Press.

Hernández, J., Cadena, A., Castaño, O., Nates, G. \& Castro, D. (1984). Diagnóstico preliminar sobre el estado actual de conocimiento acerca de la Ecología, Fauna y Flora de la Orinoquia colombiana. In memories of Encuentro de investigadores sobre la Orinoquia. Editorial Guadalupe.p. 43.

Hernández-Camacho, J., Hurtado, A., Ortiz, R. \& Walschburger, T. (1992). Unidades biogeográficas de Colombia. In Halffter, G. (Ed.). La Diversidad biológica de Iberoamérica. Pp: 105-151. México. 
IUCN. (2019). The IUCN Red List of Threatened Species. Version 2017-3. http:/ / www.iucnredlist.org. Accessed 1 February 2019. https:/ / doi.org/10.2305/ IUCN.UK.2019-2.RLTS.T4984A102881251.en

Jones, K. R., Venter, O., Fuller, R. A., Allan, J. R., Maxwell, S. L., Negret, P. J. \& Watson, E. M. (2018). One-third of global protected land is under intense human pressure. Science, 360, 788-791. https://doi.org/10.1126/science.aap9565

Lasso, C., Rial, A., Matallana, C., Ramírez, W., Señaris, J., Díaz-Pulido, A., Corzo, G. \& Machado-Allison, A. (2011). Biodiversidad de la Cuenca del Orinoco. II. Áreas prioritarias para la conservación y uso sostenible. Bogotá D.C.: Instituto de Investigación de Recursos Biológicos Alexander von Humboldt, Ministerio del Ambiente, Vivienda y Desarrollo Territorial, WWF Colombia, Fundación Omacha, Fundación La Salle de Ciencias Naturales, Instituto de Estudios de la Orinoquia (Universidad Nacional de Colombia). 303 pp.

Leisher, C., Touval, J., Hess, S. M., Boucher, T. M. \& Reymondin, L. (2013). Land and forest degradation inside protected areas in Latin America. Diversity, 5, 779-795. https:// doi.org/10.3390/d5040779

Linares, O. (1998). Mamíferos de Venezuela. Caracas: Sociedad Conservacionista Audubon de Venezuela. $691 \mathrm{pp}$.

Lira-Torres, I. \& Briones-Salas, M. (2012). Abundancia relativa y patrones de actividad de los mamíferos de los Chimalapas, Oaxaca, México. Acta Zoológica Mexicana, 28,566-585. https://doi.org/10.21829/azm.2012.283859

Lorenzo-Monterrubio, C., Cruz, L. E., Naranjo, E. J. \& Barragan, F. (2007). Uso y conservación de mamíferos silvestres en una comunidad de las cañadas de la selva lacandona, Chiapas, México. Etnobiología, 5, 99-107.

Martínez-Salas, M. P., López-Arévalo, H. F. \& SánchezPalomino, P. (2016). Cacería de subsistencia de mamíferos en el sector oriental de la reserva de Biosfera El Tuparro, Vichada (Colombia). Acta Biológica Colombiana, 21(1), 151-166. https:/ / doi.org/10.15446/abc. v21n1.49882

Minambiente (2017). Resolución No 1912 de 2017. http://www.minambiente.gov.co.
Mosquera-Guerra, F., Trujillo, F., Diaz-Pulido, A. P. \& Mantilla-Meluk, H. (2018). Diversidad, abundancia relativa y patrones de actividad de los mamíferos medianos y grandes, asociados a los bosques riparios del río Bita, Vichada, Colombia. Biota Colombiana, 19(1), 202-218. https:// doi.org/10.21068/c2018v19n01a13 Mosquera-Guerra, F., Trujillo, F., Mantilla-Meluk, H. \& Díaz-Pulido, A. (2017). Mamíferos. In Trujillo, F. \& Lasso, C. A. (Eds.). IV. Biodiversidad del río Bita, Vichada, Colombia. Pp: 305-341. Bogotá D.C.: Serie Editorial Fauna Silvestre Neotropical. Instituto de Investigación de Recursos Biológicos Alexander von Humboldt.

Muñoz-Saba, Y., Trujillo, F., Calvo-Roa, N., Cañón, S. \& Mosquera-Guerra, F. (2016). Mamíferos de las cuencas de los ríos Meta y Bita. In Trujillo, F., Antelo, R. \& Usma, R. (Eds.). Biodiversidad de la cuenca baja y media del río Meta. Pp: 248-273. Bogotá D.C.: Fundación Omacha, Fundación Palmarito.

Olarte-González, G. \& Balaguera-Reina, S. (2015). Ensamblaje de mamíferos presentes en un paisaje mixto (cultivo de palma y bosques naturales) dentro de un ecosistema de sabana en la llanura colombiana. Mammalogy Notes, 2(2), 21.

Pardo, L. E., Campbell, M. J., Cove, M. V., Edwards, W., Reuben, G. \& Laurance W. F. (2019). Land management strategies can increase oil palm plantation use by some terrestrial mammals in Colombia. Scientific Reports, 9, 7812. https://doi.org/10.1038/s41598-019-44288-y

Patton, J., Pardiñas, U. \& D’Elía, G. (2015). Mammals of South America, volume 2: rodents. Chicago, EE.UU: University of Chicago Press. 1384 pp. https:/ / doi. org/10.7208/chicago/9780226169606.001.0001

Payán-Garrido, E. \& Escudero-Páez, S. (2015). Densidad de jaguares (Panthera onca) y abundancia de grandes mamíferos terrestres en un área no protegida del Amazonas colombiano. In Payán, E., Lasso, C. A. \& Castaño-Uribe, C. (Eds.). I. Conservación de grandes vertebrados en áreas no protegidas de Colombia, Venezuela y Brasil. Pp: 225-242. Bogotá D.C.: Instituto de Investigación de Recursos Biológicos Alexander von Humboldt.

Plata, A. (2006). Uso y percepción de la fauna Silvestre en la cultura Sikuani, Comunidad de Cumariana, Selva de 
Matavén, Vichada. (Tesis de pregrado). Bogotá D.C.: Departamento de Ecología y Territorio, Facultad de Estudios Ambientales y Rurales, Pontificia Universidad Javeriana. $175 \mathrm{pp}$.

Ramírez-Chaves, H. E., Suárez-Castro, A. \& GonzálezMaya, J. (2016). Cambios recientes a la lista de los mamíferos de Colombia. Mammalogy Notes, 3, 1-9.

Ramírez-Chaves, H. E., Suárez-Castro, A. F., de Mastozoología SC, Zurc, D., Concha-Osbahr, D. C., Trujillo, A., Noguera-Urbano, E. A., Pantoja-Peña, G. E., Rodríguez-Posada, M. E., González-Maya, J. F., Pérez-Torres, J., Mantilla-Meluk, H., López-Castañeda, C., Velásquez-Valencia, A. \& Zárrate-Charry, D. (2019). Mamíferos de Colombia. Versión 1.5. Sociedad Colombiana de Mastozoología. Checklist Dataset. https:// doi.org/10.15472/kl1whs

Rangel-Ch, O., Sánchez-C, H., Lowyc, P., Aguilar-P, M. \& Castillo-G, A. (1995). Región de la Orinoquia. (Trabajo de grado). Bogotá D. C.: Instituto de Ciencias Naturales, Universidad Nacional de Colombia.

Rippstein, G., Escobar, G. \& Motta, F. (2001). Agroecología y biodiversidad de las sabanas en los Llanos Orientales de Colombia. Cali, Colombia: Centro Internacional de Agricultura tropical. 322 pp.

Rodrigues, A. S. L., Andelman, S. J., Bakarr, M. I., Boitani, L., Brooks, T. M., Cowling, R. M., Fispool, L. D. C., da Fonseca, G. A. B., Gaston, K. M. J., Hoffmann, M., Long, J. S., Marquet, P. A., Pilgrim, J. D., Pressey, R. L., Schipper, J., Sechrest, W., Stuart, S. N., Underhill, L. G., Waller, R. W., Whatts, M. E. J. \& Yan, $X$. (2004). Effectiveness of the global protected area network in representing species diversity. Nature, 428, 640-643. https:// doi.org/10.1038/nature02422

Rodríguez-Bolaños, A., Carvajal-Rojas, L. \& Ariza-Cortés, W. (2015). Fauna de los bosques de las cuencas de los ríos Planas y Tillava, Puerto Gaitán, Meta, Colombia. Bogotá D.C.: Cormacarena-Universidad Distrital Francisco José de Caldas. 280 pp.

Rodríguez-Castellanos, P., Garrote, G. \& Trujillo, F. (2017). New camera-trap records for Bush dog (Speothos venaticus) in Colombia. Galemys, 29, 1-4. https://doi.org/10.7325/Galemys.2017.N1
Rodríguez-Mahecha, J., Alberico, M., Trujillo, F. \& Jorgenson, J. (2006). Libro rojo de los mamíferos de Colombia. Bogotá D.C.: Conservación Internacional. 433 pp.

Romero, M., Trujillo, F., Lasso, C. A. \& Campo, O. (2017). Área de estudio. In Trujillo, F. \& Lasso, C. (Eds.). IV. Biodiversidad del río Bita, Vichada. Pp: 2945. Bogotá D.C.: Colombia Serie Editorial Fauna Silvestre Neotropical, Instituto de Investigación de Recursos Biológicos Alexander von Humboldt.

Rosenzweig, M. L. (2003). Win-win ecology: how the earth's species can survive in the midst of human enterprise. O Oxford; New York: Oxford University Press. Superina, M., Cortes A. \& Trujillo, F. (2019). Connecting research, management, education and policy for the conservation of armadillos in the Orinoco Llanos of Colombia. Oryx, 53(1), 17-26. https://doi.org/10.1017/S0030605318000790

Superina, M., Trujillo, F., Arteaga, M. \& Abba, A. (2014). Dasypus sabanicola. The IUCN Red List of Threatened Species, 2014. https://doi.org/10.2305/IUCN. UK.2014-1.RLTS.T6292A47441316.en

Tobler, M., Carillo-Percastegui, S., Leite-Pitman, R., Mare, R. \& Powell, G. (2008). An evaluation of camera traps for inventorying large and medium-sized terrestrial rainforest mammals. Animal Conservation, 11, 169-178. https://doi.org/10.1111/j.1469-1795.2008.00169.x

Tobler, M., Zuñiga, A., Carrillo-Percastegui, S. \& Powel, G. (2015). Spatiotemporal hierarchical modelling of species richness and occupancy using camera trap data. Journal of Applied Ecology, 52, 413-421. https:/ / doi.org/10.1111/1365-2664.12399

Trujillo, F. \& Mosquera-Guerra, F. (2016). Caracterización, uso y manejo de las mastofauna asociada a los morichales de los llanos orientales colombianos. In Lasso, C. A., Colonnello, G. \& Moraes, M. (Eds.). XIV. Morichales, cananguchales y otros palmares inundables de Suramérica Parte II: Colombia, Venezuela, Brasil, Perú, Bolivia, Paraguay, Uruguay y Argentina. Pp: 191-218. Bogotá D.C.: Serie Editorial Recursos Hidrobiológicos y Pesqueros Continentales de Colombia, Instituto de Investigación de Recursos Biológicos Alexander von Humboldt. 
Trujillo, F. \& Superina, M. (2013). Armadillos de los Llanos Orientales. Bogotá D.C.: ODL, Fundación Omacha, Cormacarena, Corporinoquia. 169 pp.

Trujillo, F., Mosquera-Guerra, F., Díaz-Pulido, A., Carvajal-Castro J. D. \& Mantilla-Meluk, H. (2018). Mamíferos de la Guayana colombiana. Pp. 345-379. In Lasso, C. A. \& Señaris J. C. (Eds.), Volumen VI. Fauna Silvestre del Escudo Guayanés (ColombiaVenezuela). Serie Editorial Fauna Silvestre Neotropical. Bogotá D. C: Instituto de Investigación de Recursos Biológicos Alexander von Humboldt.

UN Environment WCMC (2018). World database on protected areas. http:/ / www.protectedplanet.net/. Accessed September 182018
Van Schaik, C. P., Terborgh, J. \& Dugelby, B. (1997). The silent crisis: the state of rain forest nature preserves. In Kramer, R., van Schaik, C.P. \& Johnson, J. (Eds.). Last stand: Protected areas and the defense of tropical biodiversity. Pp: 64-89. New York: Oxford University Press.

Wilson, D. E. \& Reeder, D. A. M. (Eds.). (2005). Mammal Species of the World: a Taxonomic and Geographic Reference. Two volumes. Third Edition. Baltimore: The Johns Hopkins University Press. 2142 pp.

World Bank. (2018). Terrestrial protected areas (\% of total land area). The World Bank. https:/ / data.worldbank.org/indicator/ER.LND.PTLD.ZS. Accessed September 182018 


\section{Carlos A. Aya-Cuero}

Fundación Kurupira

Bogotá, Colombia

ekatenkes24@gmail.com

https://orcid.org/0000-0002-4884-4347

\section{Federico Mosquera-Guerra}

Fundación Omacha

Bogotá, Colombia

afederico.mosqueraguerra@gmail.com

https://orcid.org/0000-0002-6915-8602

\section{Diego A. Esquivel}

Fundación Kurupira

Bogotá, Colombia

diegodaem@gmail.com

https://orcid.org/0000-0001-7098-4517

\section{Fernando Trujillo}

Fundación Omacha

Bogotá, Colombia

fernando@omacha.org

https://orcid.org/0000-0002-5327-8618

\section{Daniel Brooks}

Houston Museum Natural History

Houston, USA

dbrooks@hmns.org

https://orcid.org/0000-0003-1316-690X
Medium and large mammals of the mid Planas River basin, Colombia

Citación del artículo: Aya-Cuervo, C.A., Mosquera-Guerra, F., Esquivel, D.A., Trujillo, F. \& Brooks, D. (2019). Medium and large mammals of the mid Planas River basin, Colombia. Biota Colombiana, 20(2), 76-92. DOI: 10.21068/c2019.v20n02a06.

Recibido: 3 de enero de 2019

Aceptado: 8 de agosto de 2019

92 | Biota Colombiana 20 (2) - 2019 